\title{
接合界面微細組織から見た陽極接合
}

\section{Study of Anodic Bonding on Microstructure of Joint Interface}

高 橋 誠*・池内建 二** Makoto TAKAHASHI and Kenji IKEUCHI

Key Words: Anodic Bonding, Interfacial Microstructure, Transmission Electron Microscopy, Reverse Voltage, Kovar Alloy, Silicon, Metallic Glass

\section{1. 陽極接合とは何か}

陽極接合とは、ケイ酸ガラスと金属、もしくは半導体を 接触させ、金属側を陽極として両者のあいたに数百 $\mathrm{V}$ 程度 の直流電圧を加えることで接合を行う方法である。陽極接 合の原理を Fig. 1 に示す。ほとんどのケイ酸ガラスは、軟 化温度を下げ加工を容易にするための成分として Na など のアルカリイオンを含んでいる（Fig. 1(a)）。アルカリイ オンはケイ酸ガラス中では熱拡散により移動しやすく、適 当に加熱すると熱拡散が活性化しさらに移動しやすくな る (Fig. 1(b)）。この状態のケイ酸ガラスを接合する導体 材料と接触させ、導体側を陽極として両者の間に電圧を加 えると、ケイ酸ガラス中で陽イオンであるアルカリイオン はガラス中に生じる電場から力を受けて除極側へと移動す
る (Fig. 1(c))。この Naイオンの移動はガラスを流れる電 流として観察される。この結果、導体との接触界面近傍の ケイ酸ガラス中にはアルカリイオンが久そした層が形成さ れる。この層は読んで名のごとく「アルカリイオンイオン 欠乏層」と呼ばれる。形成されるアルカリイオン欠乏層の 厚さは接合条件や使用するケイ酸ガラスの種類に依存する が、およそ数百 $\mathrm{nm}$ から数 $\mu \mathrm{m}$ の範囲である。ケイ酸ガラ ス中のアルカリイオンはもともとO イオンとバランスして 存在しているが、Oイオンはアルカリイオンほど移動度が 高くないためアルカリイオン欠乏層の中に取り残される。 そのためアルカリイオン欠乏層は強い負電荷を帯びてお り、この負電荷と、それに対応して導体表面に現れる正電 荷のあいだに働く強いクーロン力がケイ酸ガラスと導体を 密着させる。さらにアルカリイオン久乏層中では極めて強

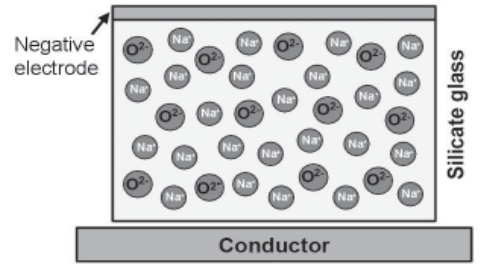

(a) Before bonding.

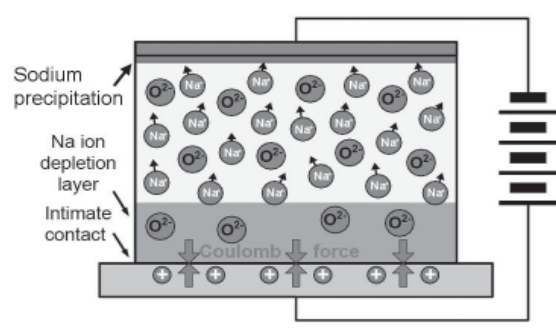

(c) Voltage application - alkali ions migrate toward the cathode, and an alkali ion depletion layer forms. A coulomb force brings the glass and the conductor into intimate contact.

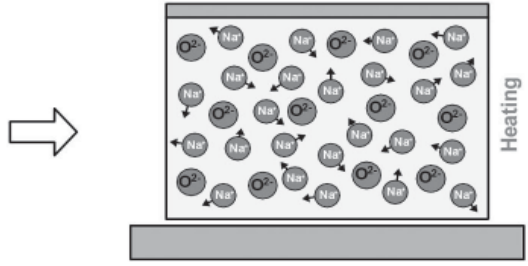

(b) Heating - activation of thermal diffusion of alkali ions in the glass.

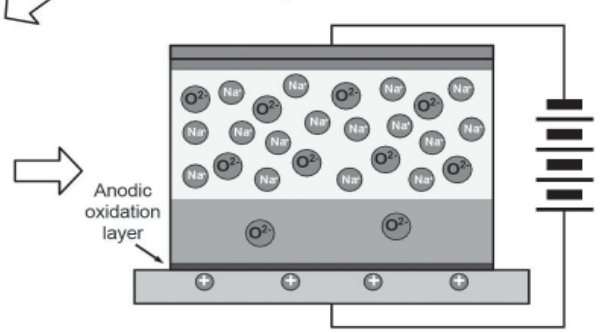

(d) Accomplishment of permanent bonding by anode oxidation of the surface of the conductor by excess oxygen in the depletion layer.

Fig. 1 Principle of anodic bonding.

* 大阪大学接合科学研究所 ( $\bar{T}$ 567-0047 大阪府茨木市美穂ヶ丘 11-1)

Joining and Welding Research Institute, Osaka University (11-1 Mihogaoka, Ibaraki, Osaka, 567-0047 Japan) **大阪大学名誉教授

Professor Emeritus, Osaka University 
い電場が働くため、移動しにくいO イオンも密着したケイ 酸ガラス／導体界面に移動して導体表面を酸化し、この反 応によって恒久的な接合が完成する ${ }^{1)}$ (Fig. 1(d))。ケイ酸 ガラス中での主要な電流キャリアは動きやすいアルカリイ オンであるため、そのアルカリイオンの久乏層の電気抵抗 はもともとのガラスと比べて非常に大きく、ガラスを流れ る電流はアルカリイオン欠乏層の成長に伴って著しく減少 する。電流が流れなくなればそれ以上のアルカリイオン欠 そ層の成長も進まなくなる。

陽極接合の特長は、比較的接合温度が低く、ケイ酸ガラ スの軟化が生じない温度で接合できるため精密接合に向 くこと、ろう材や接着剤などの介在物を用いずにケイ酸ガ ラスと金属、もしくは半導体という性質の大きく異なる素 材間の強固で気密性を有する継手を作成できることなどで ある ${ }^{2)}$ 。陽極接合の接合温度はケイ酸ガラス中のアルカリ イオンの移動が活性化される温度に依存しており主に使用 するケイ酸ガラスの種類によって決まるが、もっとも典型 的なシリコンとソーダホウケイ酸ガラス (Corning 7740、 SCHOTT TEMPAX 等) の接合では通常 600-700 K 前後であ りこの温度ではこれらのガラスは軟化しない。またガラス が脆性材料であるため継手強度の評価が難しいが、シリコ ンや多くの金属の継手でせん断試験等を行うと継手の破断 は接合界面ではなくガラス中で生じ、強固な接合界面が得 られていることがわかる。これらの特長を生かして陽極接 合は現在、主にシリコンを素材としたマイクロセンサやマ イクロマシンなどの組立に利用されている。

上に述べた原理からわかるように、陽極接合を行うため には、

・接合するガラスが動きやすい陽イオンを含む。

·陽イオンの移動後に生じる欠乏層に、強い負電荷が蓄積 する。

の 2 つの条件が必要である。陽イオンは必ずしもアルカリ イオンである必要はない。アルカリイオンでも $\mathrm{Na}$ ではな くより移動しやすい Li を用いることでより低温での陽極接 合を可能にしたガラスもある。また、 $\mathrm{Ag}$ や $\mathrm{Cu}$ はガラス中 で比較的移動しやすい陽イオンとなるが、もともと含まれ ていたNaイオンをそれらのイオンで置換したケイ酸ガラ スを作成すると、そのガラスもまた陽極接合可能である。 逆に、動きやすい陽イオンを含まないアルカリフリーガラ スや、二酸化ケイ素のみでできた石英ガラスは陽極接合で きない。また、銀や銅はケイ酸ガラスと陽極接合できない。 これは、それらの金属とケイ酸ガラスを接触させて電圧 を印加した場合、ガラスに含まれる陽イオンの移動は生じ るものの金属とガラスの接触界面近傍に生じる陽イオン欠 そ層中に移動しやすい $\mathrm{Ag}$ や $\mathrm{Cu}$ のイオンが侵入して $\mathrm{O}$ イ オンの負電荷を中和するため欠乏層に電荷が蓄積されず、 クーロン力によるガラスと金属の密着が生じないためだと 考えられる。銀や銅のようにガラスに容易に侵入する元素
を non-blocking anode と呼び、逆にほとんどガラスに侵入し ない元素を blocking anode、それらの中間的な性質を持つ元 素を partial-blocking anode と呼ぶ ${ }^{3)}$ 。陽極接合が可能な元素 は blocking、もしくは partial-blocking anode である。

\section{2. 陽極接合で形成される界面微細組織と、その継手特性 への影響}

これまでに著者らは陽極接合について、Kovar 合金とホ ウケイ酸ガラスを用いた接合の基礎的研究から始まって、 陽極接合継手に接合時と逆方向の電圧を加えたときに生じ る現象の解明、逆電圧印加による継手欠陥形成の防止、ま た新しい材料の組み合わせに対する陽極接合の適用性の検 討など、特に陽極接合界面の微細組織に注目しながらさま ざまな研究を行ってきた。ここではそれらの中から、

・Kovar 合金、アルミニウムとホウケイ酸ガラスの陽極接 合界面への反応層の形成

・陽極接合継手への逆電圧印加時に生じる現象とその原因 $\cdot \mathrm{Zr}$ 基金属ガラスへの陽極接合の適用 について解説する。

\section{1 陽極接合界面の微細組織の解明}

前に記したように、陽極接合では接合電圧の印加に伴っ てまずクーロン力による導体側材料とガラスの密着が生 じ、その後ガラスから供給される $\mathrm{O}$ と導体の表面が反応す ることで接合が完成すると考えられてきた。しかしながら この過程に伴う接合界面組織の形成は、最初の段階のクー ロン力の発生にかかわるアルカリイオン欠乏層は走査型電 子顕微鏡 $(\mathrm{SEM})$ や電子線プローブ微小分析（EPMA）を 用いて比較的容易に観察できたものの、接合を完成させる とされた酸化物の生成は、その組織が極めて微細であるこ とや、陽極接合のもっとも一般的な適用対象であるシリコ ンとガラスの継手においてはそもそもガラスも酸化ケイ素 を主成分とするため接合中に生じた酸化物とガラスの区別 が難しいことからこれを実際に観察した例がなかった。そ こで著者らは、ガラスやセラミックスとの接合によく用い られる Fe-Ni-Co 合金（Kovar 合金）とアルミニウムを導体 側材料に用いた陽極接合継手において、透過型電子顕微鏡 （TEM）を用いた接合界面の詳細な観察を行った ${ }^{4,5)}$ 。

Kovar 合金の陽極接合界面の観察は、Kovar 合金とこれ に近い線膨張率を持つホウケイ酸ガラス（Matsunami \#700） の継手から TEM 試料を作成して行った。継手作成に用い たガラス板の厚さは $1 \mathrm{~mm}$ で、接合面はガラスも導体側も 機械研磨で平坦な光沢面に仕上げた。ガラス板の厚さと継 手材料の接合面の仕上げは、特に断らない限り本稿で紹介 する全ての実験で共通である。Fig. 2 に、接合温度 $\left(T_{\mathrm{b}}\right)$ $613 \mathrm{~K}$ で接合電圧 $\left(V_{\mathrm{b}}\right) 500 \mathrm{~V}$ を $10.8 \mathrm{ks}$ の接合時間 $\left(t_{\mathrm{b}}\right)$ に わたって印加して得た継手の接合界面の微細組織を示す。

Fig. 2(a)の明視野像中には、接合界面に接したガラス側に 

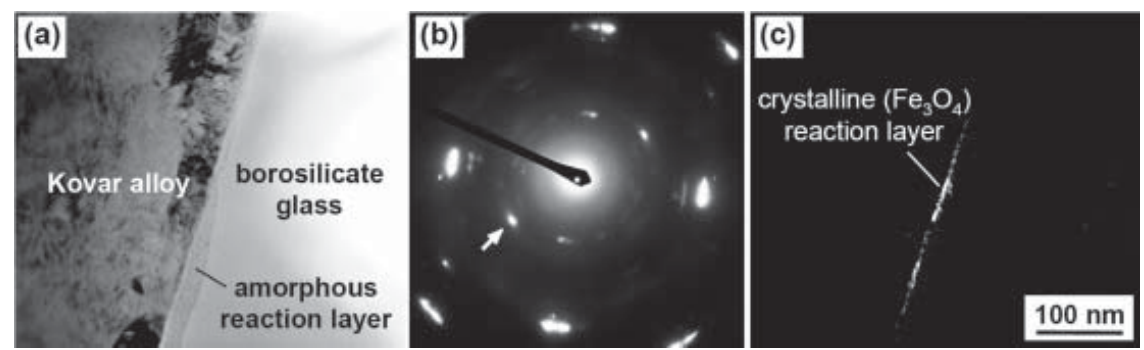

Fig. 2 Reaction layer at anodically-bonded interface of Kovar alloy to borosilicate glass. TEM bright-field image (a), SAD pattern from the interfacial area in $\mathbf{a}(\mathrm{b})$, and dark-field image taken by the extra spot indicated by an arrow in $\mathbf{b}$.
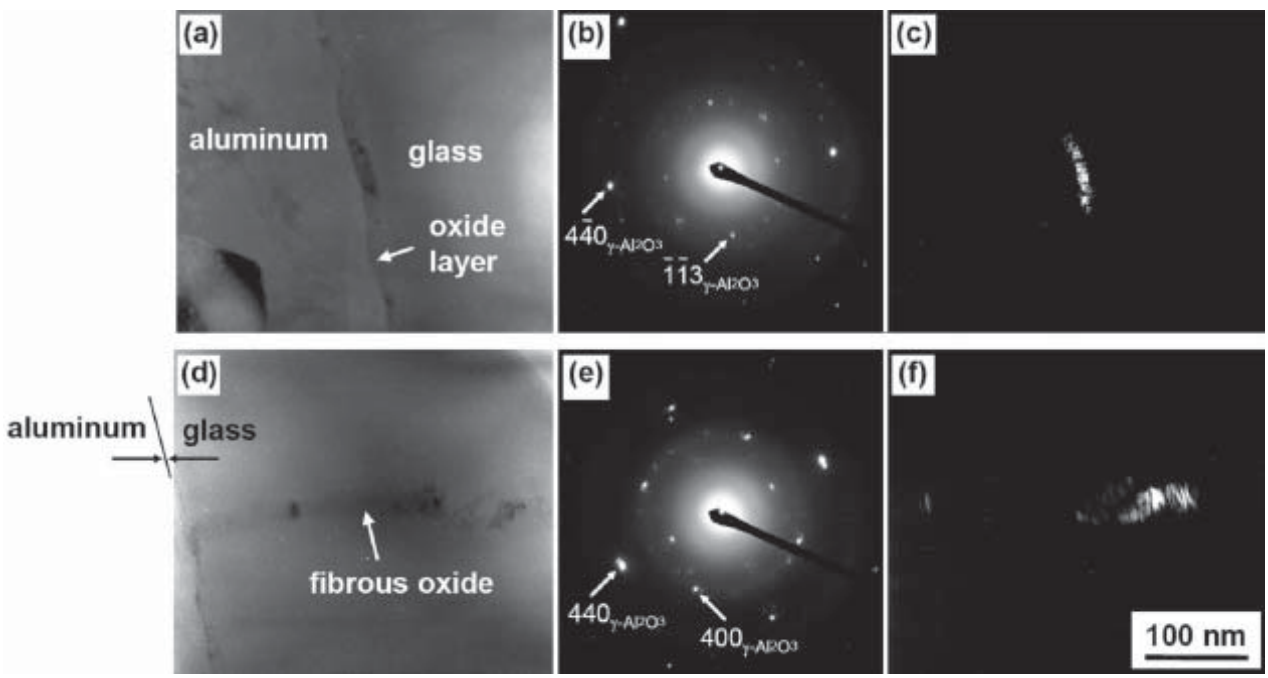

Fig. 3 Reaction products at anodically-bonded interface of aluminum to borosilicate glass. TEM bright-field image (a), SAD pattern from the oxide layer in a (b), dark-field image taken by the $4-40_{\gamma-\mathrm{Al} F \mathrm{Fe}}$ reflection in $\mathbf{b}$ (c), bright-field image (d), SAD pattern from the fibrous oxide in $\mathbf{d}(\mathrm{e})$, and dark-field image taken by $440_{\gamma \text {-Al2Fe3 }}$ reflection in $\mathbf{e}$ (f).

厚さ $30 \mathrm{~nm}$ 程度の暗いコントラストを示す層が観察される。 像のコントラストの特徵と電子線回折（SAD）の結果から この層は非晶質であり、またエネルギー分解型 X 線分光分 析（EDS）によって O、Fe、Si を多く含むことが見出され た。これらの結果から、この層は Kovar 合金中の鉄がガラ ス側に侵入することで形成された非晶質の Fe-Si 複合酸化 物層であると考えられた。この層は接合電圧の印加時間を 延長するとより厚く発達する。また明視野像でははっきり しないが、接合界面近傍から得た SAD 図形（Fig. 2(b)）中 には Kovar 合金からの反射（図形周辺部の明るいスポット） 以外に多数のエキストラスポットが観察され、その中のひ とつを用いて得た暗視野像（Fig. 2(c)）では接合界面上で 厚さ約 $5 \mathrm{~nm}$ の層が明るく見えるのが観察された。SAD 図 形の解析から、この層は鉄酸化物のマグネタイト $\left(\mathrm{Fe}_{3} \mathrm{O}_{4}\right)$ であり、Kovar 合金とホウケイ酸ガラスの陽極接合界面に 形成される酸化物は合金側に形成される結晶性の層とガラ ス側に生じる非晶質の複合酸化物層の 2 層をなすことが明 らかになった。非晶質酸化物層の形成は、従来から鉄は陽 極接合中にガラスに部分的に侵入する partial-blocking anode
であるとされていることに対応する。また Kovar 合金は Fe 以外に Ni と Co を含むが界面の酸化物層からはそれらの元 素はほとんど検出されず、接合中にはもっぱら Fe のみが優 先的に酸化されることが明らかになった。それに対応して 接合界面近傍の Kovar 合金中には Feの濃度が減少した領域 が観察された。

アルミニウムはガラスと強固に陽極接合されるが、アル ミニウムの線膨張率が大きいためバルクのアルミニウムと ガラスを陽極接合すると接合後の冷却中に熱応力でガラス が破損する。そこでアルミニウムの陽極接合界面の観察は、 厚さ $1 \mathrm{~mm}$ のホウケイ酸ガラス Corning 7740 基板の片面に 真空蒸着したアルミニウム層と基板ガラスの間に通常の陽 極接合と同様にして接合電圧を印加した後に、アルミニウ ム層とガラスの界面を含む TEM 試料を作成して行った。 真空蒸着直後のアルミニウム層は紙ワイパーなどで容易に 拭き取れるが電圧印加後はまったくはがれず、アルミニウ ム層とガラスの界面が強固に陽極接合されたことが伺われ た。 $T_{\mathrm{b}}=613 \mathrm{~K} 、 V_{\mathrm{b}}=500 \mathrm{~V} 、 t_{\mathrm{b}}=10.8 \mathrm{ks}$ の条件で陽極接合 した界面近傍の微細組織を Fig. 3 に示す。Fig. 3(a)の明視 
野像では、アルミニウムとガラスの界面に厚さ約 $15 \mathrm{~nm} の$ 反応層が生じているのが観察される。この反応層から得た $\mathrm{SAD}$ 図形 (Fig. 3(b) ) と EDSの結果からこの層は $\gamma$ アル ミナ $\left(\gamma-\mathrm{Al}_{2} \mathrm{O}_{3}\right)$ からなることが明らかになった。また、こ の層からガラス側に向かって直径 10-20 nm 程度の繊維状 の生成物が成長しているのも見出された（Fig. 3(d)）。 SAD によってこれも層状の生成物と同じく $\gamma$ アルミナであるこ とが確認された。電圧印加時間を変えた界面でこれらの生 成物の成長を観察した結果、層状の生成物の成長は早い段 階で完了するが、繊維状の生成物は時間とともに伸びてい くことがわかった。電圧印加中にガラスを流れる電流量を もとにガラスから接合界面に供給された Oの量を推定し、 TEM 観察の結果から求めた各時間における接合界面の $\gamma$ ア ルミナ生成量と比較したところ両者はよく対応し、 $\gamma$ アル ミナの生成にガラスから供給された酸素が消費されたこと が確認された。アルミニウムは陽極接合においてガラスに 侵入しない blocking anodeであるとされており、実際、繊 維状の $\gamma$ アルミナが成長している領域でも $\gamma$ アルミナの間 のガラス中の $\mathrm{Al}$ 濃度の増加は認められなかった。このこと から繊維状の $\gamma$ アルミナの成長機構は、アルミニウム層か ら供給された $\mathrm{Al}$ 原子が $\gamma$ アルミナ中を通過して繊維状の $\gamma$ アルミナの先端に達し、そこでガラス側から供給された $\mathrm{O}$ と反応してさらに繊維状の $\gamma$ アルミナを成長させたものと 考えられた。

これらの観察結果から、陽極接合界面では確かに導体材 料の酸化が生じ、その反応で生成される酸化物の形態は導 体材料によって異なることが明らかになった。

\section{2 陽極接合継手への逆電圧印加の影響}

陽極接合継手に接合時と逆向きの電圧、すなわち導体側 を陰極、ガラス側を陽極として電圧を印加すると、ガラ ス中に接合時と逆向きのイオンの流れが生じ、接合時に接 合界面から逃れるように動くアルカリイオンは逆に接合界 面に集まることになる。陽極接合継手への逆電圧の印加 は、製品の組立において例えば一枚のガラスの裏表両側に 導体を接合するような場合に実際に考えられることで、こ のことが継手の性能に影響することが懸念された。そこで Kovar 合金やシリコンの陽極接合継手に逆電圧を印加した ときに生じる現象を観察した ${ }^{6}$ 。

$T_{\mathrm{b}}=613 \mathrm{~K} 、 V_{\mathrm{b}}=500 \mathrm{~V} 、 t_{\mathrm{b}}=300 \mathrm{~s}$ の条件で接合した Kovar 合金／ホウケイ酸ガラス（Matsunami \#700）継手に、温度 $\left(T_{\mathrm{r}}\right)$ $613 \mathrm{~K}$ で逆電圧 $\left(V_{\mathrm{r}}\right) 500 \mathrm{~V}$ を時間 $\left(t_{\mathrm{r}}\right) 3.6 \mathrm{ks}$ にわたって印 加したときに接合界面に生じた変化を Fig. 4 に示す。接合 ままではほぼ全面が密着していた接合界面（Fig. 4(a)）が、 逆電圧印加後はわずかな未剥離領域を残して剥離している (Fig. 4(b))。剥離した接合面を電子線マイクロプローブ分 析（EPMA）を用いて観察したところ高濃度の Na を含む顆 粒状の生成物が多数観察され、逆電圧の印加で接合部に向

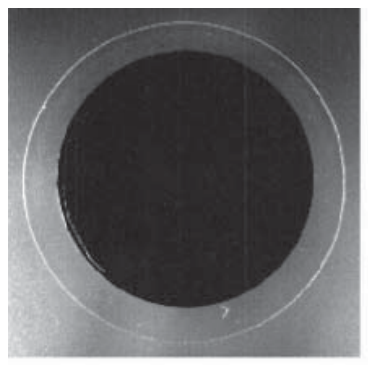

(a) as-bonded

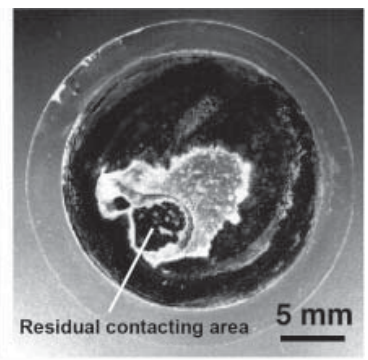

(b) after application of reverse voltage
Fig. 4 Separation of anodically-bonded interface of Kovar alloy to borosilicate glass with application of reverse voltage.
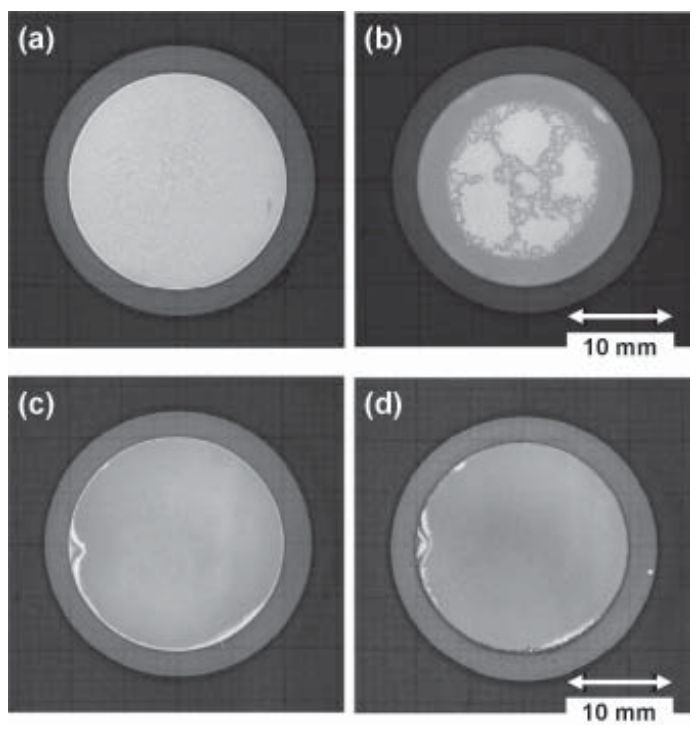

Fig. 5 Effect of application of reverse voltage on anodically-bonded interface. Joint of Kovar alloy as-bonded (a) and after application of reverse voltage (b), and joint of iron as-bonded (c) and after application of reverse voltage (d).

かって移動した Na が界面で濃縮して脆い生成物が生じ剥 離が生じたことが明らかになった。また逆電圧をより短時 間印加した継手ではただちに剥離は生じなかったが、その 後大気中に放置したり水に浸漬したりすると徐々に剥離が 進むことが見出された。これは接合界面に Naが濃縮する ことでその部分のガラスが水に溶けやすくなり、水分の影 響を受けて剥離したものと考えられた。

Kovar 合金は鉄、ニッケル、コバルトの合金であるので、 構成元素それぞれの単体の陽極接合継手に逆電圧を加えた ときの反応を知るため、Kovar 合金の表面にそれぞれの金 属を RF スパッタで製膜した表面とガラスを陽極接合し、 その継手に逆電圧を加える実験を行った。Fig. 5 に、 $T_{\mathrm{b}}=$ $613 \mathrm{~K} 、 V_{\mathrm{b}}=500 \mathrm{~V} 、 t_{\mathrm{b}}=300 \mathrm{~s}$ で接合したKovar 合金の継手 およびKovar 合金の表面に成膜した鉄単体の継手に、 $T_{\mathrm{r}}=$ 


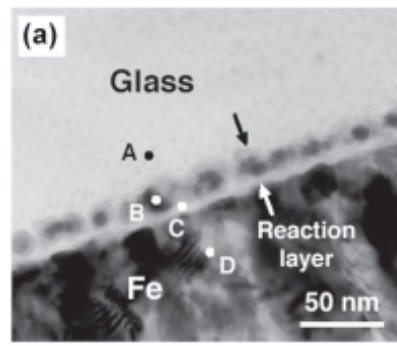

\begin{tabular}{|c|c|c|c|c|c|}
\hline (b) & Si & Fe & Al & K & $\mathrm{Na}$ \\
\hline A & 98.6 & 0.7 & 0.2 & 0.0 & 0.5 \\
\hline B & 50.8 & 45.5 & 1.7 & 2.0 & 0.0 \\
\hline C & 79.5 & 17.1 & 0.8 & 2.3 & 0.3 \\
\hline D & 1.6 & 97.4 & 0.6 & 0.0 & 0.4 \\
\hline \multicolumn{5}{|c}{ (unit: at\%) }
\end{tabular}

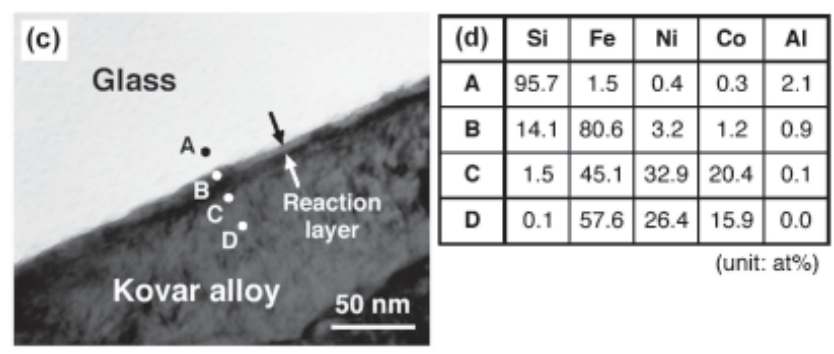

Fig. 6 Reaction layer at anodically-bonded interfaces. TEM bright-field image of iron/glass interface (a) and chemical compositions at the positions indicated by corresponding letters in a (b), and bright-field image of Kovar alloy/glass interface (c) and chemical compositions at the positions indicated corresponding letters in $\mathbf{c}(\mathrm{d})$. Chemical compositions were analyzed by EDS.
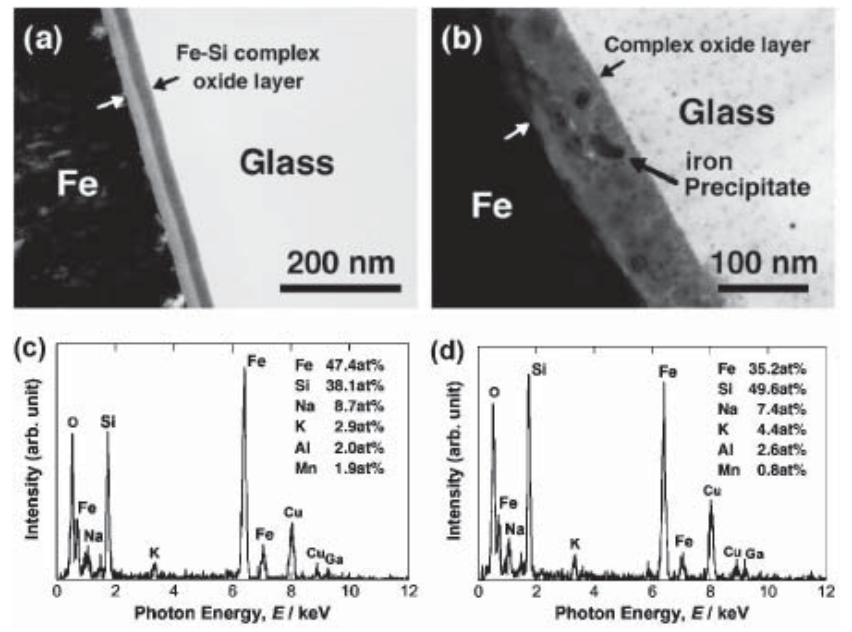

Fig. 7 Effect of application of reverse voltage on reaction layer at anodically-bonded interface of iron to glass. TEM bright-field images of as-bonded interface (a) and interface receiving reverse voltage, and EDS spectra from iron precipitate (c) and from complex oxide layer other than the precipitate (d) in $\mathbf{b}$.

$613 \mathrm{~K}$ で逆電圧 $V_{\mathrm{b}}=500 \mathrm{~V}$ をそれぞれ $600 \mathrm{~s}$ と $2400 \mathrm{~s}$ にわたつ て印加したときの接合界面の変化を示す。接合ままではい ずれの継手も接合界面のほぼ全体が密着しているが（Fig. 5(a), (c))、Kovar 合金の継手では $600 \mathrm{~s}$ の逆電圧印加で主に 界面中央部に剥離が生じたものが (Fig. 5(b))、成膜した鉄 単体の継手では $2400 \mathrm{~s}$ の逆電圧印加でも剥離が生じなかっ た（Fig. 5(d)）。この違いの原因を探るため接合ままの界面 を TEM 観察すると、鉄の継手ではKovar 合金の継手と比 べて界面の Fe-Si 非晶質複合酸化物層がより厚く成長して いるのが観察された（Fig. 6）。また鉄単体の継手で逆電圧 印加による接合界面微細組織の変化を観察すると、接合で 生じた複合酸化物層中に逆電圧印加によって接合界面に移 動してきた $\mathrm{Na}$ が分布し、複合酸化物層中の Fe が $\mathrm{Na}$ によっ て還元されて生じたと考えられる $\alpha$ 鉄の微粒子が存在する のが観察された（Fig. 7)。このことから、鉄単体の継手で は厚く成長した複合酸化物層が $\mathrm{Na}$ の濃縮による剥離の進
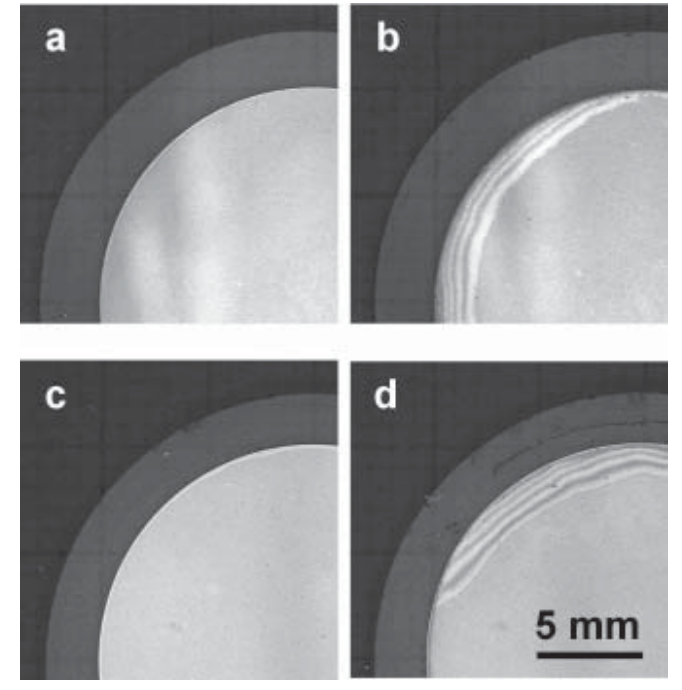

Fig. 8 Effect of application of reverse voltage on anodically-bonded interfaces. Joint of cobalt as-bonded (a) and after application of reverse voltage (b), and joint of nickel as-bonded (c) and after application of reverse voltage (d).

行を抑え、それに対して Kovar 合金の継手では、Fe の優先 的な酸化によって Kovar 合金の接合界面近傍に生じる Fe 濃 度の低下した層がそれ以上の複合酸化物層の成長を妨げた ため逆電圧印加による剥離が生じたと考えられた。

Kovar 合金に RF スパッタで成膜したコバルト単体、ニッ ケル単体の継手ではいずれでも逆電圧印加による接合界面 の剥離が生じた。Fig. 8 に $T_{\mathrm{b}}=613 \mathrm{~K} 、 V_{\mathrm{b}}=500 \mathrm{~V} 、 t_{\mathrm{b}}=300$ $\mathrm{s}$ で接合したコバルト単体の継手（Fig. 8(a)）に $T_{\mathrm{r}}=613$ $\mathrm{K} 、 V_{\mathrm{r}}=500 \mathrm{~V} 、 t_{\mathrm{r}}=1200 \mathrm{~s}$ で逆電圧を印加したときの（Fig.

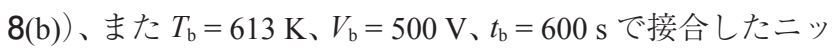
ケル単体の継手（Fig. 8(c)）に $T_{\mathrm{r}}=613 \mathrm{~K} 、 V_{\mathrm{r}}=500 \mathrm{~V} 、 t_{\mathrm{r}}=$ $1200 \mathrm{~s}$ で逆電圧を印加したときの（Fig. 8(d)）接合界面の 剥離の進行を示す。 $T_{\mathrm{b}}=613 \mathrm{~K} 、 V_{\mathrm{b}}=500 \mathrm{~V} 、 t_{\mathrm{b}}=600 \mathrm{~s}$ で接 合したニッケル単体の継手の接合界面を TEM 観察したが、 鉄の継手で見出されたような明りょうな酸化物反応層は観 


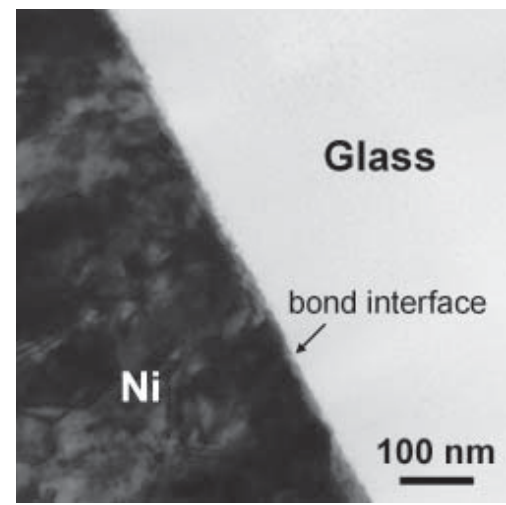

Fig. 9 TEM micrograph of anodically-bonded interface of nickel to borosilicate glass.
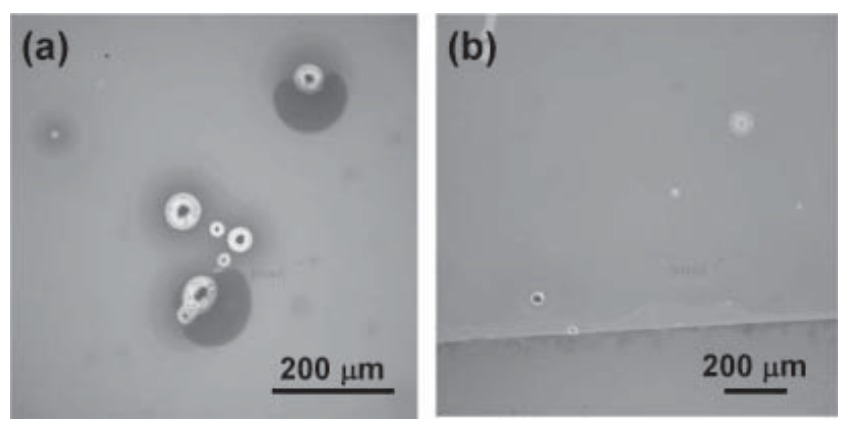

Fig. 10 Anodicall-bonded interface of silicon to borosilicate glass Corning 7740 (a) and Matsunami $\# 700$ (b) receiving reverse voltage.

察されなかった（Fig. 9)。

シリコンを Corning 7740 と Matsunami \#700の 2 種類の ホウケイ酸ガラスと陽極接合した継手に逆電圧を印加する と、接合界面にそれぞれ様子の異なる変化が生じた。接合 はともに $T_{\mathrm{b}}=563 \mathrm{~K} 、 V_{\mathrm{b}}=500 \mathrm{~V} 、 t_{\mathrm{b}}=400 \mathrm{~s}$ の条件で、逆電 圧印加は $T_{\mathrm{r}}=563 \mathrm{~K} 、 V_{\mathrm{r}}=500 \mathrm{~V} 、 t_{\mathrm{r}}=500 \mathrm{~s}$ の条件で行った。 Corning 7740 の継手では接合界面に多数の褐色の斑点が生 じ、それらの斑点の多くはガラスの亀裂を伴っていた（Fig. 10(a)）。接合界面の断面を EPMA で観察すると、褐色の斑 点の部分では界面に $\mathrm{Na}$ が強く濃縮しているのが見出され た。Matsunami \#700の継手ではこのような斑点は生じず、 接合界面全体が淡黄色に変色した（Fig. 10(b)）。接合界面 断面の EPMA 観察では界面全体に Na の濃縮が観察された。 逆電圧印加後のそれぞれの継手を水に浸漬したところ、接 合界面全体が黄変した Matsunami \#700の継手では界面全体 で、褐色の斑点が生じた Corning 7740 の継手では接合界面 の周縁で変色部が水に接したところのみで剥離が生じた。 同じシリコンの陽極接合継手でも、ガラス側を Matsunami \#700 とした継手では逆電圧印加によって接合界面に移動し
た Naが界面にほぼ一様に分布したのに対し、Corning 7740 を用いた継手では Na が界面の一部に集中し、その部分で ガラスの亀裂などを生じたものと考えられた。

このように、陽極接合継手への逆電圧の印加は接合界面 へのアルカリイオンの濃縮を引き起こし、継手材料によっ て界面の剥離、変色、耐水性の低下などの種々の欠陥をも たらすことが明らかになった。

逆電圧印加による接合界面へのアルカリイオンの濃縮に よって生じる継手欠陥の発生を抑制するため、ガラスの接 合面近傍のアルカリイオンを、アルカリイオン同様にガラ ス中で動きやすい $\mathrm{Ag} 、 \mathrm{Cu}$ のイオンで置換したガラスを陽 極接合に用いることを試みた ”。接合面から表層部、深さ $10 \mu \mathrm{m}$ 程度の範囲のアルカリイオンを $\mathrm{Ag}$ イオンで置き換 えたガラスは元のガラスと同様の陽極接合性を示した。ま た、 $\mathrm{Ag} 、 \mathrm{Cu}$ によるイオン置換を行ったガラスの陽極接合 継手に逆電圧を印加すると、接合界面に濃縮するイオンは アルカリイオンではなく $\mathrm{Ag} 、 \mathrm{Cu}$ のイオンになるので接合 界面近傍のガラス中にこれらの金属の微細な析出物が形成 されたが、それに伴って接合界面の剥離やガラスの亀裂等 の継手欠陥が生じることはなかった。また継手の耐水性の 低下も生じなかった。

\section{3 金属ガラスの陽極接合}

近年研究が進んでいる金属ガラスには、高い強度、小さ なヤング率、高い耐食性など従来の結晶性の金属材料では 得がたい優れた特性がある。また等方的で均一な性質を示 すため、転写加工やビーム加工による精密微細加工を適用 しやすい。これらの利点を生かした金属ガラスの応用対象 として、従来はシリコンなどの材料で製作されている圧力 センサ等の各種センサ類が考えられる ${ }^{8)}$ 。従来からその種 の素子の封止技術として、精密接合に適しており真空封止 もできる陽極接合が広く用いられている。従って金属ガラ スのセンサ類への応用を実現するには金属ガラスにも陽極 接合を適用できることが望ましい。そこで金属ガラスの陽 極接合性を確かめるため $\mathrm{Zr}$ 基金属ガラス $\mathrm{Zr}_{55} \mathrm{Cu}_{30} \mathrm{Al}_{10} \mathrm{Ni}_{5}$ と ケイ酸ガラスとの陽極接合を試みた 9”。

用いた $\mathrm{Zr}$ 基金属ガラスの線膨張率は室温付近で $10 \times 10^{-6}$ $/ \mathrm{K}$ の程度と報告されている ${ }^{10)}$ 。そこでこれと接合するケイ 酸ガラスにはこれに近い線膨張率 $\left(8.7 \times 10^{-6} / \mathrm{K}\right)$ を持つソー ダライムガラスを選択した。 $\mathrm{Zr}$ 基金属ガラスは厚さ $2 \mathrm{~mm}$ の板を $10 \mathrm{~mm}$ 角に、ソーダライムガラスは厚さ $1.3 \mathrm{~mm} の$ 板を $25 \mathrm{~mm}$ 角に切断し、いずれも接合面は研磨紙による機 械研磨ののち、ダイヤモンドペーストによるバフ仕上げで 平坦な光沢面に仕上げた。Fig. $11 に V_{\mathrm{b}}=500 \mathrm{~V} て ゙ 、$ 接合温 度と電圧印加時間を変えて接合した継手の外観を示す。 $T_{\mathrm{b}}$ $=423 \mathrm{~K}$ から $623 \mathrm{~K}$ の範囲でほぼ接合界面全体が密着した 継手が得られた。接合温度が高くなると接合界面の変色が 強くなる傾向が見られた。これは金属ガラスの成分元素が 


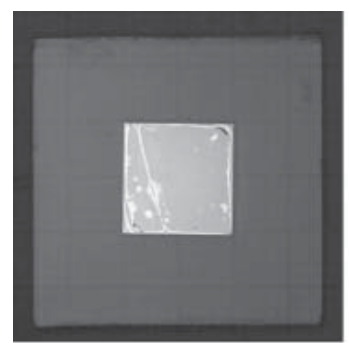

$T_{\mathrm{b}}=473 \mathrm{~K}, t_{\mathrm{b}}=7200 \mathrm{~s}$

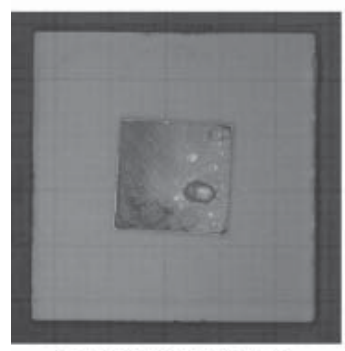

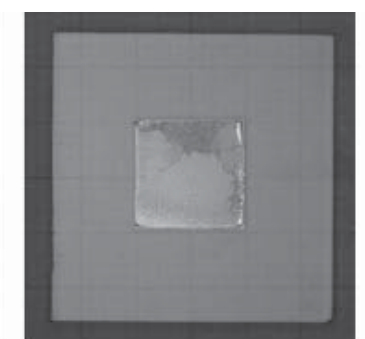

$T_{\mathrm{b}}=523 \mathrm{~K}, t_{\mathrm{b}}=4800 \mathrm{~s}$

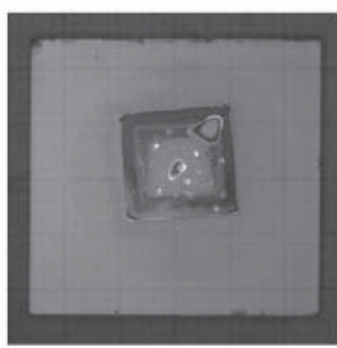

$T_{\mathrm{b}}=573 \mathrm{~K}, t_{\mathrm{b}}=1200 \mathrm{~s}$

$T_{\mathrm{b}}=623 \mathrm{~K}, \mathrm{t}_{\mathrm{b}}=60 \mathrm{~s}$

$10 \mathrm{~mm}$

Fig. 11 Appearances of anodically-bonded interfaces of Zr-based metallic glass to soda-lime glass.
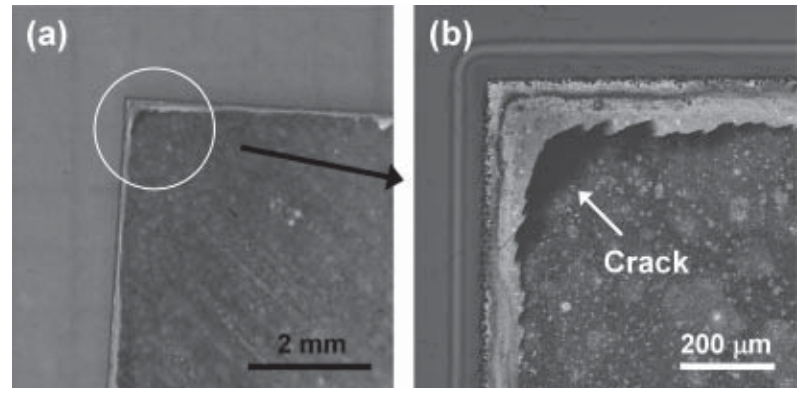

Fig. 12 Crack in glass in anodically-bonded joint of Zr-based metallic glass to soda-lime glass. Low magnification image (a) and high magnification image (b).

酸化されたためだと考えられる。接合界面の密着は得られ たものの、得られた全ての継手でガラスに亀裂が生じてい るのが観察された。 $T_{\mathrm{b}}=573 \mathrm{~K} 、 V_{\mathrm{b}}=500 \mathrm{~V} 、 t_{\mathrm{b}}=1200 \mathrm{~s}$ で接 合した界面の周縁部を Fig. 12 に示す。これは金属ガラス とソーダライムガラスの線膨張率のマッチングが十分でな く、接合後の冷却中に生じる熱応力がもっとも集中する接 合界面周縁部の角の位置でソーダライムガラスが割れたも のと考えられた。亀裂の発生はしかし、接合界面が、熱応 力が生じてもそこで剥離するのではなく母材が壊れる程度 の強度を有していることも示している。接合した金属ガラ スが金属ガラスとしての性能を発揮するためには、接合の プロセスで金属ガラスが結晶化することなく非晶質の状態 を保たなくてはならない。接合中の結晶化の有無を確かめ るため、 $T_{\mathrm{b}}=573 \mathrm{~K} 、 V_{\mathrm{b}}=500 \mathrm{~V} 、 t_{\mathrm{b}}=1200 \mathrm{~s}$ で接合した界

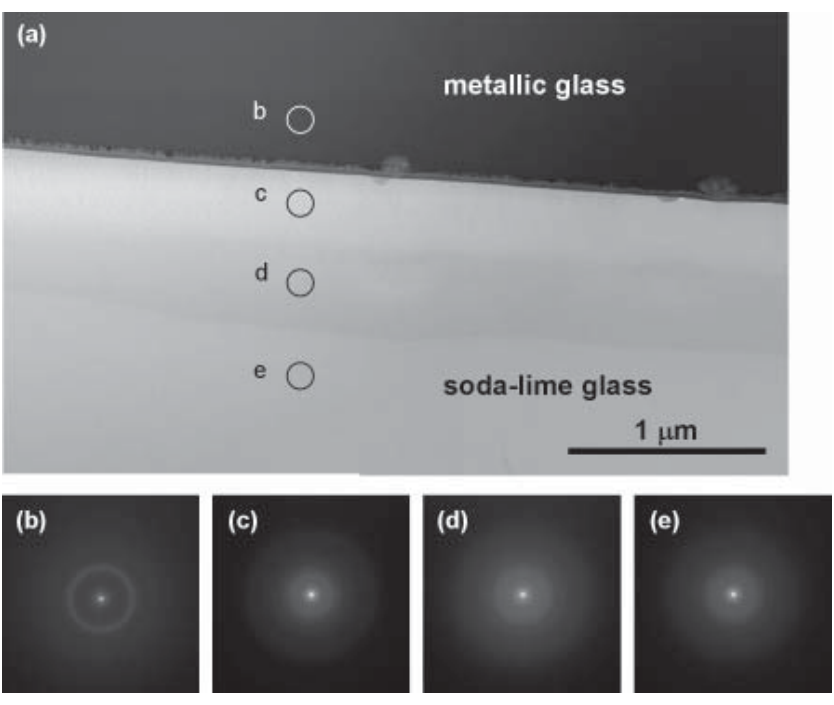

Fig. 13 Anodically-bonded interface of Zr-based metallic glass to sodalime glass. TEM bright-field image (a) and SAD patterns from positions indicated by corresponding letters in a (b)-(e).

面近傍の微細組織を TEM 観察した（Fig. 13）。金属ガラス とソーダライムガラスの界面には反応層が見られるが、そ れ以外の金属ガラス部分は均一なコントラストを示してお り、そこから得られた SAD 図形は非晶質を示すハローパ ターンで結晶質からのシャープな回折スポットは見出され なかった（Fig. 13(b)）。陽極接合の接合温度は用いた金属 ガラスの結晶化温度より十分に低いので、金属ガラスの再 結晶は生じなかったものと考えられた ${ }^{10)}$ 。ソーダライムガ ラス中には何層かコントラストの違う部分が見られたが、 それらの部分から得られた SAD 図形はいずれも非晶質の ハローパターンであり、ソーダライムガラスの結晶化や析 出物の出現は見出されなかった（Fig. 13(c)-(e)）。コントラ ストの違いは陽極接合中に生じたイオンの移動によって生 じた局所的な組成の違いを反映している。接合界面をより くわしく観察した結果を Fig. 14 に示す。界面上には、金 属ガラスに接した不均一なコントラストを示す厚さ約 20 $\mathrm{nm}$ の層と、ソーダライムガラスに接したほぼ均一なコン トラストを示す厚さ約 $40 \mathrm{~nm}$ の層の 2 つの反応層があっ た（Fig. 14(a)）。これらの層を含む部分から得た SAD 図形 (Fig. 14(e)）には非晶質のハローと結晶質のシャープな回 折スポットが含まれていたが、結晶質の回折スポットを用 いて得た暗視野像中で明るく見えたのは金属ガラスに接し た層の一部であり (Fig. 14(b)-(d))、これと EDS 分析 (Fig. 14(f)）の結果から、金属ガラスに接した層は金属ガラスの 全ての構成元素を含む結晶質の酸化物、ソーダライムガラ スに接した層は $\mathrm{Cu}$ が欠損した非晶質の酸化物であること がわかった。

$\mathrm{Zr}$ 基金属ガラスとソーダライムガラスとの陽極接合で 

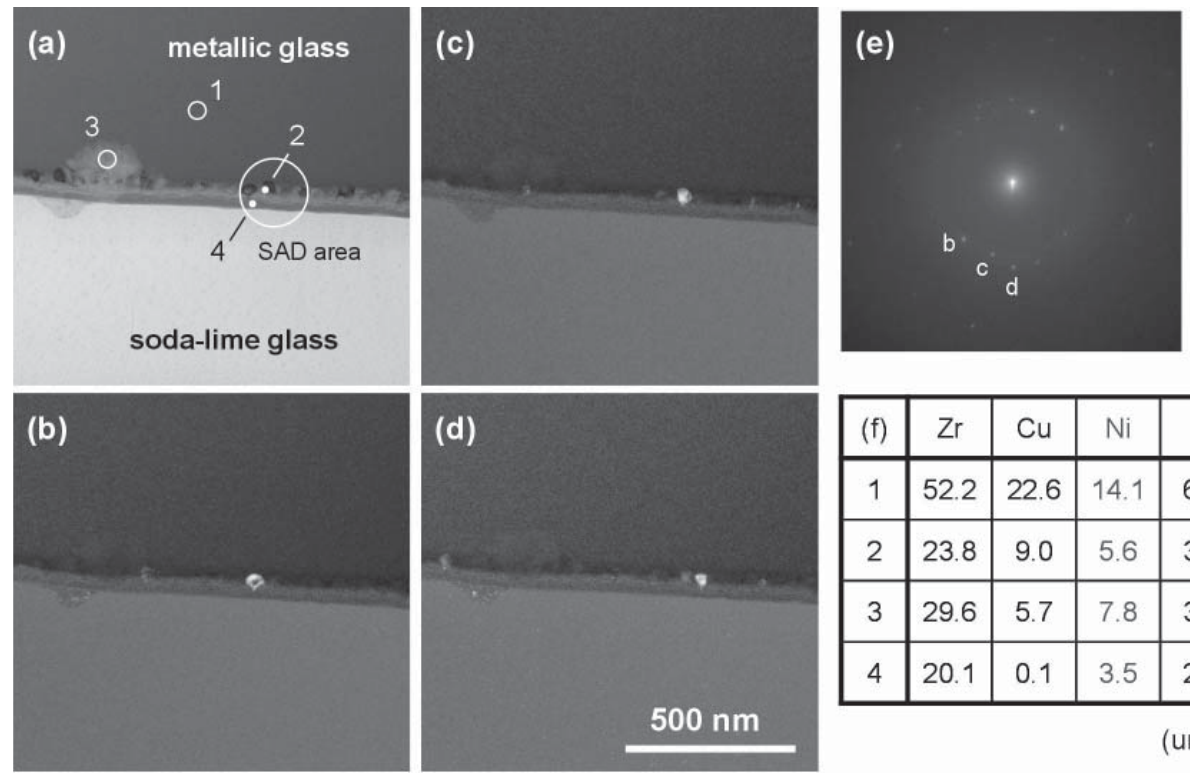

\begin{tabular}{|c|c|c|c|c|c|}
\hline$(f)$ & $\mathrm{Zr}$ & $\mathrm{Cu}$ & $\mathrm{Ni}$ & $\mathrm{Al}$ & $\mathrm{O}$ \\
\hline 1 & 52.2 & 22.6 & 14.1 & 6.9 & 4.2 \\
\hline 2 & 23.8 & 9.0 & 5.6 & 3.9 & 57.7 \\
\hline 3 & 29.6 & 5.7 & 7.8 & 3.9 & 53.0 \\
\hline 4 & 20.1 & 0.1 & 3.5 & 2.4 & 73.9 \\
\hline \multicolumn{5}{c}{ (unit: at\%) }
\end{tabular}

Fig. 14 Reaction products at anodically-bonded interface of Zr-based metallic glass to soda-lime glass. TEM brightfield image (a), dark-field images taken by reflections indicated by corresponding letters in e (b)-(d), SAD pattern from bond interface in a (e), and chemical compositions at positions indicated by corresponding numbers in a (f). Chemical compositions were analyzed by EDS.

は接合界面の周縁部からソーダガラス内部に亀裂が生じた が、同じ $\mathrm{Zr}$ 基金属ガラスの陽極接合で、ケイ酸ガラス側 の材料にソーダライムガラスより少し線彭張率の大きいも のを用いることでケイ酸ガラスの亀裂のない継手を得る ことができた。 $T_{\mathrm{b}}=523 \mathrm{~K} 、 V_{\mathrm{b}}=500 \mathrm{~V} 、 t_{\mathrm{b}}=300 \mathrm{~s}$ で接合し たソーダアルミノケイ酸ガラス Matsunami 801（線䐍張率 $\left.10.7 \times 10^{-6} / \mathrm{K}\right)$ の継手、 $T_{\mathrm{b}}=563 \mathrm{~K} 、 V_{\mathrm{b}}=500 \mathrm{~V} 、 t_{\mathrm{b}}=300 \mathrm{~s}$ で 接合したソーダカリガラス Matsunami 7622 (線膨張率 $12 \times$ $\left.10^{-6} / \mathrm{K}\right)$ の継手の外観を Fig. 15 に示す。 Matsunami 801 の 継手は接合界面全体が密着して㧍り（Fig. 15(a), (b)）、7622 の継手は周縁部にわずかに未密着部が残っているが（Fig. 15(c), (d)）いずれの継手でもガラスの亀裂は生じていない。

\section{3. おわりに}

以上、著者らがこれまでに行ってきた陽極接合に関する 研究をいくつか紹介した。

陽極接合にはその接合のメカニズムにまだ十分わかって いない部分が残っている。例えば、一般に接合を行うに は材料の接合面の污染層を除去して、得られた新鮮表面同 士を原子レベルで密着させなくてはならないとされている が、陽極接合には污染層の除去で新鮮表面を得る過程がな く、研磨などで仕上げた表面同士を接触させるだけである。 それにもかかわらず多くの場合力学試験では接合界面では なくガラス内部で破断が生じる強い継手が得られる。また 陽極接合では導体材料の接合面がガラス側から供給される 酸素と反応することで接合が完成するとされているが、こ
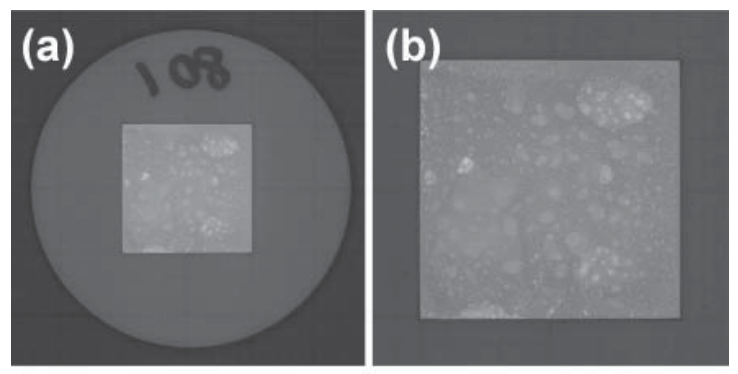

801 silicate glass joint

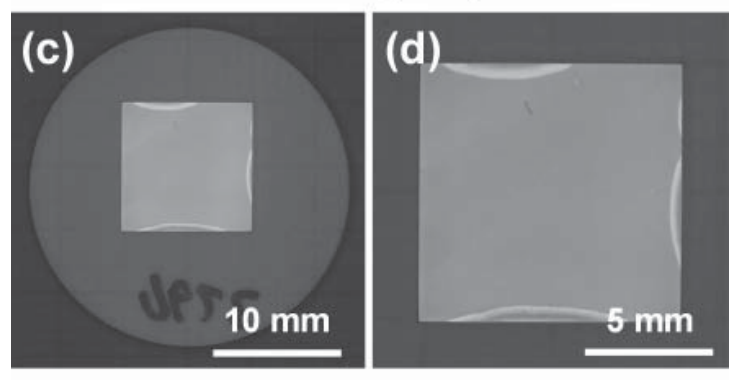

7622 silicate glass joint

Fig. 15 Appearances of anodically-bonded joints of Zr-based metallic glass to soda-alumino silicate glass Matsunami 801 (a), (b) and soda-potash silicate glass Matsunami 7622 (c), (d).

のとき生じる酸化物の役割も明らかでない。これらは全て 接合界面の微細組織の構造とその形成に関わる問題であ り、今後解明を進めていきたいと考えている。 
実用的には、陽極接合は材料の変形をほとんど伴わない ため接合面の仕上げなどに対する要求が厳しく、精密接合 の有力な手法とはいうものの逆に言えば現在のところ精密 接合にしか使えない方法とも言える。この点を克服し、ま た適用できる材料の範囲を広げられれば、簡単な方法でガ ラスと導体の強固な継手が得られる陽極接合は今後さらに 応用の対象を増やしていけるのではないかと考えている。

\section{謝 辞}

金属ガラスの陽極接合の研究は、「3 大学 3 研究所連携金 属ガラス・無機材料接合技術開発プロジェクト」の一環と して行われたものであり、用いた金属ガラス材料は東北大 学 金属材料研究所からご提供いただいた。ここに感謝の 意を表する。

\section{引用文献}

1) G. Wallis and D. I .Pomerantz: J. Appl. Phys., 40(1969), p3946-3949

2) K. Hiller, R. Hahn, C. Kaufmann, S. Kurth, K. Kehr, T. Gessner, W.
Doetzel, M. Wiemer and I. Schubert: Proc. SPIE - The International Society for Optical Engineering, 3878(1999), p58-66

3) D. E. Carlson, K. W. Hang and G. F. Stockdale: J. Amer. Ceram. Soc., 55(1972), p337-341

4) M. A. Morsy, K. Ikeuchi, M. Takahashi and M. Ushio: ASM Proc. the International Conference: Trends in Welding Research, 1998, p251-256

5) M. Takahashi and K. Ikeuchi: ASM Conference Proc. Joining of Advanced and Specialty Materials, 2001, p61-68

6) M. Takahashi, H. Yasuda and K. Ikeuchi: Solid State Ionics, 172(2004), p335-340

7) M. Takahshi and K. Ikeuchi: Proc. the 3rd International Brazing and Soldering Conference, 2006, p60-66

8）井上 明久：七十七ビジネス情報 1007 年夏季号 (No. 38), 2007, p18-27

9) M. Takahashi, K. Ikeuchi, H. Kimura and A. Inoue: Trans. JWRI, 38(2009), p25-29

10) T. Terajima, K. Nakata, H Kimura and A. Inoue: Mater. Trans., JIM, 50(2009), p1322-1325 